\title{
The Role of Purinergic Receptors in Cancer-Induced Bone Pain
}

\author{
Sarah Falk, Maria Uldall, and Anne-Marie Heegaard \\ Department of Drug Design and Pharmacology, Faculty of Health and Medical Sciences, University of Copenhagen, \\ 2100 Copenhagen, Denmark \\ Correspondence should be addressed to Anne-Marie Heegaard, amhe@sund.ku.dk
}

Received 9 April 2012; Accepted 22 August 2012

Academic Editor: Niklas Rye Jørgensen

Copyright (c) 2012 Sarah Falk et al. This is an open access article distributed under the Creative Commons Attribution License, which permits unrestricted use, distribution, and reproduction in any medium, provided the original work is properly cited.

Cancer-induced bone pain severely compromises the quality of life of many patients suffering from bone metastasis, as current therapies leave some patients with inadequate pain relief. The recent development of specific animal models has increased the understanding of the molecular and cellular mechanisms underlying cancer-induced bone pain including the involvement of ATP and the purinergic receptors in the progression of the pain state. In nociception, ATP acts as an extracellular messenger to transmit sensory information both at the peripheral site of tissue damage and in the spinal cord. Several of the purinergic receptors have been shown to be important for the development and maintenance of neuropathic and inflammatory pain, and studies have demonstrated the importance of both peripheral and central mechanisms. We here provide an overview of the current literature on the role of purinergic receptors in cancer-induced bone pain with emphasis on some of the difficulties related to studying this complex pain state.

\section{Introduction}

Cancer-induced bone pain significantly compromises the quality of life of many cancer patients. A large proportion of patients with bone metastasis experience severe pain and bone pain is often the first sign of metastatic spread in patients suffering from breast, lung, or prostate cancer. Current treatment options are radiotherapy, anti-inflammatory agents, opioids, and bisphosphonates, but still up to $45 \%$ of patients are left with inadequate pain control [1-4]. The poor management of cancer-induced bone pain is a consequence of the complexity of the pain state, involving a combination of both background pain and breakthrough pain. The background pain is described as a constant pain with increasing intensity as the disease progresses and can usually be treated with opioids with a satisfying result. Breakthrough pain can be divided into movement-evoked pain and spontaneous pain. These pain states, which have a rapid onset and a short duration of 15-30 minutes [1], are generally difficult to treat. Opioids given orally have a slow onset of analgesia of approximately 30 minutes, that is, an analgesic effect only at the end of the average breakthrough pain episode, if at all. Additionally, oral opioids have a long duration of action, typically $4-6$ hours, which is much longer than required to treat breakthrough pain episodes [5] and often causes dose-limiting side effects [6]. A rapid onset and short acting opioid such as sublingual or nasal spray fentanyl is a more promising approach for the treatment of breakthrough pain [3].

In order to accommodate the clinical need for new and improved therapies of cancer-induced bone pain, a better understanding of the mechanisms underlying the pain state is needed. Cancer-induced bone pain exhibits components of both inflammatory and neuropathic pain, but the complete mechanism is not yet fully characterized [7]. When tumor cells invade the bone tissue, multiple mechanisms are initiated. Osteoclasts are stimulated resulting in increased bone degradation with release of growth factors from the bone matrix, and as the tumor cells invade the bone, they compress and damage the sensory fibers present in the bone. Also inflammatory cells infiltrate the tissue and release various cytokines and growth factors [8] that may contribute to the development and maintenance of the pain state. Furthermore, cancer-induced bone pain causes cellular and neurochemical changes in the spinal cord which appear to be mechanistically distinct compared to neuropathic or inflammatory pain states [7].

The advanced understanding of the underlying mechanisms of cancer-induced bone pain is mainly due to the recent development of in vivo bone cancer models displaying 
pain-related behavior mimicking the clinical condition. Since the first murine model of cancer-induced bone pain was developed in 1999 [9], various syngeneic animal models of cancer-induced pain states have been developed in rodents. The rodent models are based on direct injection of cancer cells into the intramedullary space of femur, humerus, or tibia or in and around calcaneus [10]. This allows correlation of tumor growth, tumor microenvironment, bone destruction, and neurochemistry with site-specific painrelated behaviors and has given new insight into the different cellular and molecular mechanisms driving cancer-induced bone pain and thereby provided opportunities to develop targeted therapies [10]. A number of cytokines, growth factors, and other molecules such as tumor necrosis factoralpha (TNF- $\alpha$ ), nerve growth factor (NGF), bradykinins, and prostaglandins have thus been identified to play a role in cancer-induced bone pain [11-14]. Adenosine 5-triphophate (ATP), which plays a key role in nociception, both as a neurotransmitter and as a modulator of glial activity, has also been identified to be involved in cancer-induced bone pain. This paper provides an overview of current knowledge regarding the role of purinergic receptors in cancer-induced bone pain.

\section{ATP and Purinergic Receptors}

The involvement of ATP and purinergic signaling in nociception has long been recognized. Already back in 1966 Collier et al. reported that ATP could initiate pain when applied to human skin [15]. However, extracellular ATP was not accepted as a functional neurotransmitter until the 1990s. Today, the role of ATP in pain transmission is well established [15-18].

ATP is an agonist for two classes of purinergic receptors, the ligand gated ion channels, $\mathrm{P} 2 \mathrm{X}$ receptors (P2X1-7) and the $\mathrm{G}$ protein-coupled P2Y receptors (P2Y1, 2, 4, 6, 11-14). The P2X receptors consist of two transmembrane domains with intracellular $\mathrm{N}$ - and C-terminals and a long extracellular loop between the transmembrane regions. The extracellular domain contains binding sites for ATP, competitive antagonists and modulatory metal ions [19-22]. The $\mathrm{N}$-terminal has similar length in all subtypes, whereas the C-terminal varies considerably from 30 residues in the $\mathrm{P} 2 \mathrm{X} 6$ receptor to 240 residues in the $\mathrm{P} 2 \mathrm{X} 7$ receptor $[18,23]$, indicating that the different functional properties of the subtypes are linked to the $\mathrm{C}$-terminal. A characteristic of the $\mathrm{P} 2 \mathrm{X} 7$ receptor, but also some of the other P2X receptors, is the ability to induce pore formation allowing the permeation of large molecules [24-26]. The P2X receptors form homoor heterotrimeric ATP-gated nonselective cation channels [23]. The P2Y receptors contain seven transmembrane regions similar to other $G$ protein-coupled receptors [18]. Unlike the P2X receptors, which are all stimulated by native ATP and synthetic ATP analogues, most of the P2Y receptors have greater affinity for ADP, UTP, or UDP [27].

The P2 receptors are found on almost every cell in the body [27]. When it comes to their involvement in chronic pain states, some purinergic receptors have been much more intensely studied than others. In the 1990s the first antagonists for the $\mathrm{P} 2 \mathrm{X}$ receptors became available $[28,29]$ and this, together with recent development of various knockout models, has facilitated the investigation of the purinergic system in chronic pain states. A solid amount of data have demonstrated a key role of especially the $\mathrm{P} 2 \mathrm{X} 3$ receptor, but also the $\mathrm{P} 2 \mathrm{X} 4$ and $\mathrm{P} 2 \mathrm{X} 7$ receptors in the development of both neuropathic and inflammatory pain $[16,30]$, and recently the number of studies on other P2X and also P2Y receptor subtypes are starting to rapidly expand the field. In relation to cancer-induced bone pain the involvement of the purinergic receptors is still poorly understood, but purinergic receptors are speculated to be important for the nociceptive transmission in cancerinduced bone pain for multiple reasons. First of all, the involvement of ATP in other chronic pain states, such as neuropathic and inflammatory pain, has been firmly established [16]. Secondly, nociceptors have been found to project not only to the periosteum, but also deeply into the bone and bone marrow and are therefore in close proximity to both tumor cells and tumor-associated immune cells and stromal cells. Thirdly, growing tumor cells are thought to release ATP, thus possibly producing a microenvironment of extracellular ATP stimulating the P2 receptors directly at the peripheral terminals of the nociceptors.

Although, an understanding of the role of purinergic signaling in the pathogenesis of cancer-induced bone pain is slowly emerging, the studies are complicated by molecular and cellular variation among the different in vivo models. One of the complicating factors is the variation in expression pattern of various purinergic receptors on the nociceptors in different models, as described in the following sections.

\section{Purinergic Receptor Expression on Nociceptive Neurons}

The nociceptive neurons are specialized pseudounipolar primary afferent neurons having their cell bodies in the dorsal root ganglion (DRG) or trigeminal ganglion and projecting to both the peripheral sites and the dorsal horn of the spinal cord [31]. Sensory afferent fibers can be divided into two major populations, the myelinated A-fibers and the nonmyelinated C-fibers, with the C-fibers often being further classified into peptide-rich and a peptidepoor groups according to the neuropeptides, receptors and channels they express, and the A-fibers being classified into thick $\mathrm{A} \alpha$ - and $\beta$-fibers and thin $\mathrm{A} \delta$-fibers. $\mathrm{A} \delta$ - and $\mathrm{C}$ fibers, and possibly $A \beta$-fibers are considered nociceptors $[31,32]$, and it is generally accepted, at least for skin, that the myelinated $\mathrm{A} \delta$-fibers conduct the fast signal, perceived as the sharp "first pain," whereas the slower nonmyelinated C-fibers conduct the more dull "secondary pain" [31]. From the DRG the nociceptive neurons project to different laminae in the dorsal horn, thereby grouping them into anatomical subpopulations. The myelinated $\mathrm{A} \delta$-fibers and the peptidergic population of the C-fibers send input to lamina I and the outer part of lamina II. The nonpeptidergic 
population of the C-fibers project to the inner lamina II, whereas the deeper layers, such as lamina $\mathrm{V}$, only receives few input from $\mathrm{A} \delta$-fibers [33].

Even though the expression of the $\mathrm{P} 2 \mathrm{X}$ and $\mathrm{P} 2 \mathrm{Y}$ receptors on the nociceptive neurons has been intensively studied, the expression pattern is still not clear, as conflicting results are reported. The characterization of the expression pattern is complicated by species differences $[34,35]$, and variation is observed in different compartments of the neurons, as some receptors are expressed both at the peripheral and central projections and in the cell body, whereas others might only be expressed at the central or peripheral terminals.

When studying the expression of $\mathrm{P} 2 \mathrm{X}$ receptors on peripheral terminals, most information is currently found on the P2X3 receptor. In contrast to many of the other P2X receptors, which are found on various cell types throughout the body, the P2X3 receptors are predominantly expressed in small- and medium-sized sensory neurons (C- and A $\delta$ fibers), and presumably in both the cell body and the peripheral and central terminals $[35,36]$. P2X3 receptors are mainly expressed on an $\mathrm{IB}_{4}$-expressing subpopulation of the nociceptive neurons, with up to $94 \%$ of the P2X3 receptorpositive neurons also expressing $\mathrm{IB}_{4}[37,38]$. However, variation in expression has been demonstrated for the $\mathrm{P} 2 \mathrm{X} 3$ receptor at both the peripheral and central terminals of the afferent neurons, and this is likely similar for the other P2 receptors. For instance, different models of neuropathic pain have demonstrated opposite responses in the expression of the P2X3 receptor depending on which method was used to induce the peripheral injury. Whereas one model showed downregulation of $\mathrm{P} 2 \mathrm{X} 3$-receptors in the spinal cord, another displayed an increase in the number of P2X3positive neurons in both the DRGs and the spinal cord [37, 39]. Furthermore, the expression level can change at both the peripheral and central terminals according to different peripheral stimuli, such as nerve damage, inflammation or tumor growth [40-42].

When moving from the peripheral terminal to the cell body of the nociceptors in DRG, more information about the expression pattern is starting to accumulate. In the dorsal root and trigeminal ganglia up to $90 \%$ of the neurons express various subtypes of $\mathrm{P} 2 \mathrm{X}$ receptors. With the exception of the P2X7 receptor all of the subtypes are present, however, at different expression levels and with the $\mathrm{P} 2 \mathrm{X} 3$ receptors more highly expressed than the remaining P2 receptors [43, 44]. In rats up to $40 \%$ of the DRG neurons express P2X3 receptors $[38,43]$. Of these $73-84 \%$ also express P2Y1, while $25-35 \%$ are expressing P2Y4 [45]. Using immunohistochemistry, $\mathrm{P} 2 \mathrm{X} 2$ and $\mathrm{P} 2 \mathrm{X} 3$ receptors have been demonstrated to display a high degree of colocalization in rat DRG, although singlelabeled neurons are also present, and $\mathrm{P} 2 \mathrm{X} 2$ receptors are also observed in satellite cells [34]. Whereas the expression of P2X3 receptors in DRG is fairly well established, the reports on the expression of the remaining subtypes are still conflicting.

At the level of the dorsal horn the same confusion seems to exist when it comes to the distribution of the different P2X subtypes. Attempting to clarify the matter, Aoyama et al. recently reported a systematic analysis of the distribution of all seven P2X receptors in the dorsal horn and compared their findings to earlier reports [46]. From this they concluded that P2X1 and P2X3 receptor subunits are densely distributed mainly in laminae I and II of the dorsal horn and are presumably expressed at the afferent nerve terminals [38]. This is in agreement with earlier studies reporting $\mathrm{P} 2 \mathrm{X} 3$-expressing projections from nonpeptidergic nociceptive DRG neurons to lamina II $[37,38]$. For the P2X2 receptor Aoyama et al. concluded that it was only weakly expressed in the fibers of the dorsal roots, and almost completely absent in the gray matter, whereas earlier reports have demonstrated dense P2X2 receptor immunostaining in the spinal cord, especially in the dorsal horn [47]. In addition, while Aoyama et al. reported P2X4 receptor expression in small cells in the entire dorsal horn and in dorsal root fibers and neuropils surrounding neurons, others have demonstrated $\mathrm{P} 2 \mathrm{X} 4$ receptor expression in microglia, but not in astrocytes and neurons in the dorsal horn [48, 49]. Also, P2X7 receptors were strongly detected in dorsal root fibers, in neuropils in the entire dorsal horn, and also in astrocytes. The expression on astrocytes is supported by functional studies in astrocyte cultures isolated from both the spinal cord, cerebral cortex, and hippocampus [50-53]. However, this is inconsistent with other studies reporting expression in microglia, but not in astrocytes and neurons $[54,55]$. As this summary illustrates, the expression profile of the P2X receptors is unclear, and both the spatial and temporal distributions are likely affected by species variation, method of nerve injury and peripheral stimuli.

\section{P2X Receptors at the Peripheral Site in Relation to Cancer-Induced Bone Pain}

The bone is innervated by a tight network of both sympathetic and sensory neurons, and although the periosteum seems to be the most densely innervated part, when the total volume of each tissue is considered, the bone marrow is receiving the greatest number of nerve fibers followed by the mineralized part of the bone and lastly the periosteum [56, 57]. In rodents, both myelinated A-fibers and unmyelinated peptidergic C-fibers are found throughout the periosteum, in the compact and trabecular part of the mineralized bone and in the bone marrow $[56,58]$. The innervation of the bone by nociceptors has, in addition to traditional immunohistochemical analysis, been established using retrograde labeling demonstrating that the size, neurochemistry, and segmental distribution of the neuronal projection from the bone to the DRG and dorsal horn are consisting with a functional role in nociception [59].

The expression of $\mathrm{P} 2 \mathrm{X}$ and $\mathrm{P} 2 \mathrm{Y}$ receptors on both nerves and bone cells is interesting in several aspects in relation to cancer-induced bone pain. During the last decade a number of groups have reported expression of both P2X and $\mathrm{P} 2 \mathrm{Y}$ receptors in osteoblasts, including $\mathrm{P} 2 \mathrm{X} 1-7$ and $\mathrm{P} 2 \mathrm{Y} 1$, $2,4,6$ and 12-14, and in osteoclasts, including P2X1-5 and 7 and P2Y1-2, 4-6 and 11-14 [60]. The action of P2 receptors on osteoclasts includes $\mathrm{P} 2 \mathrm{X} 2$-induced bone resorption, increased osteoclast formation and bone resorption through P2Y1 receptor activation, increased survival by P2Y6 
receptor activation, and $\mathrm{P} 2 \mathrm{X} 7$-mediated precursor cell fusion and decreased apoptosis (although there have been reports on increased apoptosis) [60]. The presence of P2X and P2Y receptors on osteoblasts, and especially on osteoclasts, could be essential for understanding the progression of cancerinduced bone pain. For instance, it has been demonstrated that low concentrations of extracellular ATP stimulates resorption pit formation by mammalian osteoclast [61]. This is speculated to be controlled by the action of the $\mathrm{P} 2 \mathrm{X} 2$ receptors, which are the only of the $\mathrm{P} 2$ receptors that require extracellular acidification to be fully activated by ATP $[62,63]$. Moreover, P2X2 receptor knockout mice display an phenotype with increased bone mass, further pointing to the involvement of P2X2 receptors in bone turnover [64]. As cancer-induced bone pain is correlated with degradation of the bone [65], and tumor cells probably release ATP, is it likely that these events are linked together through the action of purinergic receptors on the osteoclasts, a likely candidate being the $\mathrm{P} 2 \mathrm{X} 2$ receptors.

Tumor cells have also been shown to have a direct effect on the organization of the nerves innervating the bone, as it has recently been reported that bone cancer induces sprouting and disorganization of both sensory and sympathetic fibers in the periosteum through the action of NGF in a murine model of cancer-induced bone pain [66]. How this interruption of the normal innervation is effecting the expression of the purinergic and other nociceptive receptors, and thereby the transmission of the nociceptive signal to the spinal cord is clearly target for further investigation.

So far, the $\mathrm{P} 2 \mathrm{X} 3$ receptor is the most studied purinergic receptor in relation to cancer-induced bone pain (Table 1). Several studies have investigated the neuronal expression of the $\mathrm{P} 2 \mathrm{X} 3$ receptor and the effect of $\mathrm{P} 2 \mathrm{X} 3$ receptor inhibitors in various models of cancer-induced bone pain [41, 42, 67-70]. An upregulation of $\mathrm{P} 2 \mathrm{X} 3$ receptor expression on epidermal nerve fibers overlaying a cancer-induced area was demonstrated by Gilchrist et al. in a murine model of cancer-induced pain where osteolytic sarcoma cells were implanted in and around the calcaneous bone [41]. In addition, an increase in the number of $\mathrm{P} 2 \mathrm{X} 3$ receptor positive small cells in the trigeminal ganglions was found in a rat model of oral cancer pain [42]. This suggested a role of the $\mathrm{P} 2 \mathrm{X} 3$ receptor in cancer-induced bone pain; however, neither of these studies investigated the expression of the P2X3 receptor on nerve fibers in bone. The P2X3 receptor has been shown to be mainly expressed on the $\mathrm{IB}_{4}$-expressing population of the nonpeptidergic $\mathrm{C}$-fibers $[37,38,56]$ and according to Mach et al. $\mathrm{IB}_{4}$ positive fibers are not present in the mouse periosteum, mineralized bone or bone marrow [56]. Moreover, in a study with naïve mice it was demonstrated that even through the skin was tightly innervated by $\mathrm{P} 2 \mathrm{X} 3$ receptor-expressing afferent neurons, the nerve fibers innervating the periosteum, mineralized bone and bone, marrow did not express P2X3 receptors [58]. It is possible that the expression level of neuronal P2X3 receptors in bone depends on the local environment and that tumor cells and their associated stromal cells release factors such as NGF [66] that induce novel P2X3 expression
[71]. Species differences might also play a role as rat studies using the retrograde tracer fast blue injected into tibial bone have shown $\mathrm{P} 2 \mathrm{X} 3$ receptor immunostaining and also $\mathrm{IB}_{4}$ binding in retrogradely labeled dorsal root ganglion neurons $[59,67]$. Furthermore, some of the fast-blue positive neurons were both $\mathrm{P} 2 \mathrm{X} 3$ receptor positive and calcitonin gene-related peptide-positive indicating that $\mathrm{P} 2 \mathrm{X} 3$ receptors are not only expressed in the non-peptidergic C-fibers as has been assumed for a long time, but also in at least some of the peptidergic C-fibers [67]. Based on this it is still conceivable that $\mathrm{P} 2 \mathrm{X} 3$ receptors are expressed in sensory neurons innervating tumor infiltrated bone and that ATP released from cancer cells, acting through $\mathrm{P} 2 \mathrm{X} 3$ receptor signaling, contributes to the cancer-induced bone pain.

The recent development of selective P2X3 receptor antagonists has provided the tools for further investigating the role of $\mathrm{P} 2 \mathrm{X} 3$ receptor-mediated purinergic signaling in cancerinduced bone pain [72]. The competitive antagonist A317491 blocks both $\mathrm{P} 2 \mathrm{X} 3$ and $\mathrm{P} 2 \mathrm{X} 2 / 3$ receptors [73] and was shown to attenuate pain-related behaviors in two different murine models and a rat model of cancer-induced bone pain [68-70]. González-Rodríguez et al. showed that A-317491 injected subcutaneously over a tibial tumor mass dosedependently inhibited tumor-induced thermal hyperalgesia in the affected limb but not in the nontumor bearing limb. Interestingly, coadministration of an anti-met-enkephalin antibody abolished the antihyperalgesic effect of A-317491 suggesting that in this model the effect of A-317491 occurs through stimulation of peripheral opioid receptors [68]. The involvement of endogenous opioid mechanisms in P2X3 and $\mathrm{P} 2 \mathrm{X} 2 / 3$ receptor-related antinociception has also been described in rat models of inflammatory pain [74].

An antinociceptive effect of A-317491 in cancer-induced bone pain was further demonstrated in a study by Hansen et al. where A-317491 was administered systemically in a murine model with mammary carcinoma cells injected into the femoral medullar cavity. Chronic administration of A-317491 resulted in an attenuation of pain-related behaviors in the early stage of the bone cancer model; however, no effect of neither chronic nor acute treatment with A-317491 was observed in the late and progressed stages of the pain model [69]. The limited effect of A317491 in the cancer model might be explained by its pharmacokinetic properties. A-317491 has a high plasma protein binding and a limited CNS penetration which makes it less suitable for in vivo testing and indicates that the effect of A-317491 is predominantly in the periphery [72]. An additional explanation for the lack of effect of A-317491 in the progressed stage of cancer-induced bone pain could be that the expression or activity of the P2X 3 and $\mathrm{P} 2 \mathrm{X} 2 / 3$ receptors changes with the development of the cancer and/or that other nociceptive mechanisms dominate at this stage. A recent rat study by Kaan et al. also showed less analgesic effect of $\mathrm{P} 2 \mathrm{X} 3$ receptor inhibition in the late stage of cancerinduced bone pain [67]. Kaan et al. used AF-353 (RO4 ) in a rat model of tibial cancer-induced bone pain. AF353 potently blocks $\mathrm{P} 2 \mathrm{X} 3$ and $\mathrm{P} 2 \mathrm{X} 2 / 3$ receptors and in contrast to A-317491 it has low plasma protein binding and good CNS penetration. Oral administration of AF- 


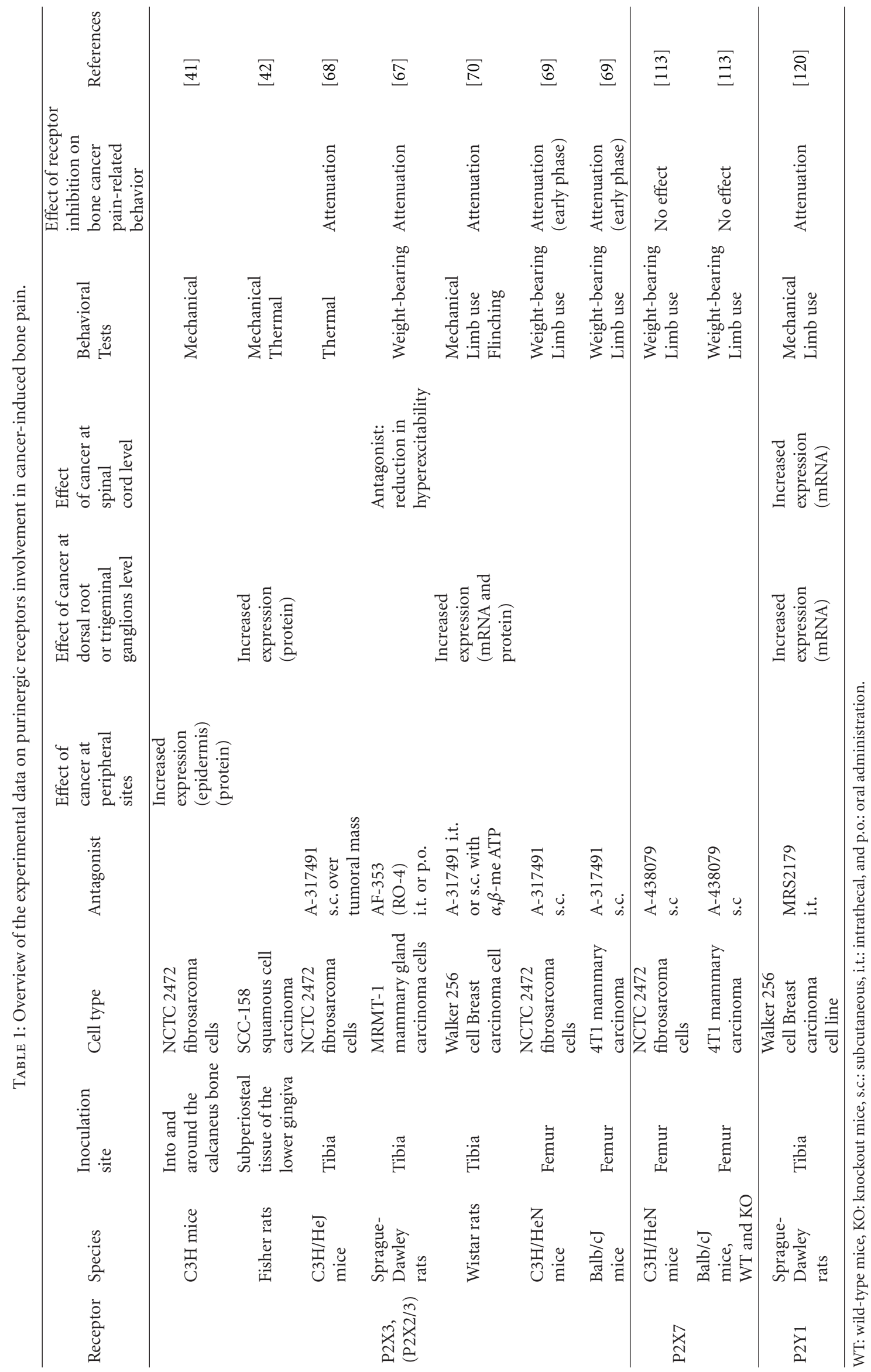


353 in a prophylactic treatment regimen reduced cancerinduced pain-related behaviors to the level of control rats, and some effect of AF-353 was also observed when it was given at a more progressed disease stage [67]. Both peripheral and central effects of P2X3 receptor inhibition were suggested. The argument for a peripheral effect was based on experiments showing that MRMT-1 carcinoma cells release ATP in vitro and that a P2X3 receptor-mediated increase in phosphorylated ERK immunoexpression was found in dorsal root ganglion neurons cocultured with MRMT-1 cell, indicating an activation of the ERK-signaling pathway. Although this is in agreement with other studies demonstrating enhanced phosphorylated ERK expression in models of chronic pain [75], the results remain to be confirmed in vivo.

A central effect of AF-353 was investigated by administering AF-353 directly into the spinal cord of cancer bearing rats. AF-353 dose-dependently reduced the electrically evoked responses observed in the $\mathrm{A} \delta$ - and C-fibers of the dorsal horn, and additional a significant reduction in the postdischarge was found at the high doses of AF-353, together suggesting that the cancer-induced hyperexcitability of the dorsal horn neurons can be modulated by P2X3 and $\mathrm{P} 2 \mathrm{X} 2 / 3$ receptor antagonism [67]. Taken together, the results described above provide evidence that inhibition of P2X3 and $\mathrm{P} 2 \mathrm{X} 2 / 3$ receptor activity at the periphery and at the level of the spinal cord could have therapeutic potential in the treatment of cancer-induced bone pain. It should be noted that although many of the purinergic receptors are expressed in bone cells, it is unlikely that the effect of P2X3 and $\mathrm{P} 2 \mathrm{X} 2 / 3$ receptor antagonism is mediated through decreased bone destruction. None of the $\mathrm{P} 2 \mathrm{X} 3$ and $\mathrm{P} 2 \mathrm{X} 2 / 3$ receptor antagonist studies found any effect on bone destruction and only very few osteoclasts express functional $\mathrm{P} 2 \mathrm{X} 3$ receptors [76].

\section{The Role P2X Receptors at the Central Level of Nociception}

A state of hypersensitivity is introduced in the spinal cord as a response to peripheral nociceptive stimuli in chronic pain states. The hypersensitivity is a consequence of the highly complex processing and modulation of the peripheral nociceptive input through excitatory and inhibitory mechanisms in the dorsal horn of the spinal cord causing a general state of hyperexcitability in the neurons [77]. The output from the dorsal horn will under normal conditions be balanced by excitatory and inhibitory control mechanisms, but in pathological pain states the output is greatly increased, caused by increased excitatory synaptic transmission and/or suppressed inhibitory transmission. Increasing evidence points to the interaction of neurons and nonneuronal cells to be the underlying cause of this hypersensitivity, and various molecular and cellular changes in the spinal cord have been observed in different chronic pain states. Interestingly, inflammatory, neuropathic, and cancer-induced pain states can be distinguished by these neurochemical changes in the spinal cord. In models of inflammatory pain an increased level of substance $\mathrm{P}$ and calcitonin gene-related peptide includes some of the changes, whereas neuropathic models display an opposite decreased expression of the same molecules [7]. For the cancer-induced pain state the changes in the spinal cord include increased expression of c-Fos in laminae I and II, increase in the number of dynorphin-expressing neurons, and often massive astrocyte hypertrophy without neuronal loss [7, 9, 78, 79].

Purinergic signaling is a key element in the modulation of the hypersensitivity at the level of the spinal cord. ATP mediates neuron-neuron, neuron-glia, and glia-glia communication through activation of purinergic receptors expressed in the presynaptic terminals of the afferent sensory neurons in the spinal cord, in postsynaptic neurons, and in spinal microglia and astrocytes $[35,72,80,81]$. The importance of the purinergic receptors, especially in microglia, is well established in animal models of both neuropathic and inflammatory pain [81], but much is still quite unexplored when it comes to their role in cancer-induced bone pain.

The P2X4 receptor is a good example of a purinergic receptor recognized to be important for the microgliamediated contribution to neuropathic pain [48]. In responce to peripheral nerve injury a de novo expression of $\mathrm{P} 2 \mathrm{X} 4$ receptors occurs in microglia in the dorsal horn, which, upon stimulation by ATP released from the afferent neurons, results in activation of $\mathrm{p} 38$-mitogen-activated protein kinase (MAPK), leading to synthesis and exocytotic release of brain-derived neurotrophic factor (BDNF) [49, 82, 83]. The released BDNF induces, through the activation of the TrkB receptor, a depolarizing shift in the anion reversal potential in lamina I neurons, causing a general neuronal hyperexcitability in lamina $I$ by reducing $\mathrm{GABA}_{\mathrm{A}}$-ergic and glycinergic inhibition [84]. The $\mathrm{P} 2 \mathrm{X} 4$ receptors have not been directly linked to cancer-induced bone pain, but might be indirectly involved, as the pain state displays some elements of neuropathic pain caused by compression of the peripheral nociceptive terminals as the tumor grows.

The specific role of microglial $\mathrm{P} 2 \mathrm{X} 7$ receptors is still not fully understood, but is speculated to contribute to the hyperexcitability through the action of both TNF- $\alpha$ and interleukin-1 $\beta$ (IL-1 $\beta$ ) [54, 85-88]. ATP, for example, released from astrocytes and acting through microglial P2X7 receptors has been reported to be an endogenous factor causing microvesicle shedding and IL- $1 \beta$ release in microglia [89]. ATP is released from astrocytes both through vesicular release [90] and via various membrane channels, such as connexin [91] and pannexin [92], and possible through P2X7 receptor pore formation [53, 93]. The function of the $\mathrm{P} 2 \mathrm{X} 7$ receptors in astrocytes is recognized to be tightly linked to the hyperexcitation of the dorsal horn neurons, not only through release of IL- $1 \beta$ and ATP, but also through glutamate signaling [50]. It has been reported that peripheral nerve injury results in an initially increased, but later persistent decreased expression of glutamate transporter-1 and glutamate-aspartate transporter in astrocytes [94-97] and that activation of the $\mathrm{P} 2 \mathrm{X} 7$ receptors could decrease glutamate uptake in both astrocytes and microglia [98100]. This means that stimulation of astrocytes is not only causing ATP-induced ATP release, and thereby activation of 
neighboring neurons, microglia, and astrocytes through their purinergic receptors, but also that the glutamate released upon stimulation is inadequately removed from the synapse, additional contributing to a general hyperexcitation of the postsynaptic neurons and further adding to the stimulation of the neighboring astrocytes.

The ability of the $\mathrm{P} 2 \mathrm{X} 7$ receptor as well as the $\mathrm{P} 2 \mathrm{X} 2$ and $\mathrm{P} 2 \mathrm{X} 4$ receptors to induce membrane permeabilization to large molecules has long been recognized and the mechanisms underlying this have been widely studied. Contrary to the P2X2 and P2X4 receptors that do not seem to rely on pannexin hemichannel association for pore formation $[26,101]$, the $\mathrm{P} 2 \mathrm{X} 7$ receptor can associate with pannexin- 1 to form large pores [102-104]. However, recent studies have shown that Pannexin-1 is not always involved in P2X7-receptormediated pore formation and other interactions as well as intrinsic ion channel dilation are possible mechanisms [105$108]$.

The P2RX7 gene is highly polymorphic and several nonsynonymous single nucleotide polymorphisms (SNPs) have been shown to affect either receptor channel function or pore function or both [109]. Multiple studies have connected specific P2X7 receptor SNPs to diseases such as bipolar and major depression disorders, infections, cancer, and some bone diseases $[109,110]$; however, it is only recently that variations in the P2X7 receptor gene have been associated with pain [111]. Sorge et al. demonstrated that interstrain variation in mice specifically affecting the pore forming function of the $\mathrm{P} 2 \mathrm{X} 7$ receptor influences the hypersensitivity developed in neuropathic and inflammatory pain states. Mice carrying a mutation causing impaired pore formation demonstrated less pain-related behavior than mice with normal pore formation properties of the $\mathrm{P} 2 \mathrm{X} 7$ receptor. In addition, administration of a peptide, which blocked pore formation, also reduced pain-related behavior. Together these data indicate that it might be the properties related to pore formation and not to channel function which affect chronic pain states. The effect was found to translate to humans, as a genetic association between lower pain intensity and a hypofunctional allele of the P2X7 receptor was found in a cohort study of patients with chronic pain [111].

The importance of the P2X7 receptor in both neuropathic and inflammatory pain has additionally been demonstrated using P2X7 receptor knockout mice [112, 113]. The development of both thermal and mechanical hypersensitivity following nerve ligation was completely absent in the P2X7 receptor knockout animals, and, in addition, the animals did not develop hypersensitivity following intraplantar injections of a proinflammatory agent. The baseline nociceptive behavior was, however, unaffected, as their response to noxious heat was similar to the wild-type animals in the absence of any neuropathic or inflammatory insult [112]. Unexpectedly, it was found that the P2X7receptor-deficient mice were susceptible to cancer-induced bone pain and even had an earlier onset of pain-related behavior compared to cancer-bearing wild-type mice. Furthermore, no effect of $\mathrm{P} 2 \mathrm{X} 7$ receptor inhibition was found when the P2X7 receptor antagonist A-438079 was tested in two different murine models of cancer-induced bone pain.
A-438079 was applied in a model with no cancer-induced microglial or astrocyte activation $(\mathrm{BALB} / \mathrm{cJ})$ and in one with strong astrogliosis, but no microglial activation $(\mathrm{C} 3 \mathrm{H} / \mathrm{HeN})$. Inhibiting the P2X7 receptors did not alleviate pain-related behaviors in either of the models, suggesting that the P2X7receptor-mediated contribution to the progression of the cancer-induced pain state in these murine models is limited. Neither of the models had microglial activation, which might explain the lack of effect of P2X7 receptor inhibition. This could reflect a species difference, since microglia activation seems to be important for the progression of cancer-induced bone pain in rat models $[114,115]$. Wang et al. reported an upregulation of the microglia/macrophage marker OX42 and of BDNF in the spinal cord 6 days after tibial cancer cell inoculation in a rat model of cancer-induced bone pain. Intrathecal injection of minocycline, an inhibitor of microglial activation, resulted in a decrease in painrelated behaviours and decreased OX-42 and BDNF mRNA expression in the dorsal horn. The antinociceptive effect of minocycline was only present, when the compound was injected at the early stage of disease.

Complicating the interpretation of data from $\mathrm{P} 2 \mathrm{X} 7$ receptor knockout mice is the fact that the mice used in the pain experiments express a splice variant of the P2X7 receptor that escaped deletion [116]. This rodent splice variant, $\mathrm{P} 2 \mathrm{X} 7 \mathrm{k}$, uses an alternative exon 1 compared to the P2X7a variant. The $\mathrm{P} 2 \mathrm{X} 7 \mathrm{k}$ and $\mathrm{P} 2 \mathrm{X} 7 \mathrm{a}$ variants have different, but overlapping, expression, and the $\mathrm{P} 2 \mathrm{X} 7 \mathrm{k}$ variant is activated by lower ATP and bzATP concentrations than the P2X7a variant $[108,116]$. Recently it was shown that the splice variants are differentially affected by a P451L SNP. Only the P2X7a variant was sensitive to the P451L SNP, which affects pore formation [108].

\section{P2Y Receptors in relation to Cancer-Induced Bone Pain}

Compared to the $\mathrm{P} 2 \mathrm{X}$ receptors, the $\mathrm{P} 2 \mathrm{Y}$ receptors are less studied in relation to chronic pain states. P2Y12 is expressed on microglia cells, and is, like P2X4, upregulated in response to peripheral nerve injury $[117,118]$. Activation of the P2Y12 receptors results in phosphorylation of MAPK [117], thereby possibly linking the action of the P2Y12 receptor to the P2X4-mediated BDNF release. A role of P2Y12 in pain-related behavior has been demonstrated in models of neuropathic pain in rats. In these models intrathecal administration of different P2Y12 antagonists and antisense knockdown of P2Y12 expression suppressed the development of pain-related behaviors, and additionally intrathecal infusion of a P2Y12 agonist was found to elevate pain-related behavior in naïve rats $[117,118]$. Several other types of $\mathrm{P} 2 \mathrm{Y}$ receptors, such as the $\mathrm{P} 2 \mathrm{Y} 2$ and $\mathrm{P} 2 \mathrm{Y} 1$ receptors, have begun to be recognized to contribute to the hypersensitivity that occurs in chronic pain states. The P2Y1 receptors are localized on small diameter neurons in DRG and are like many of the other purinergic receptors upregulated in response to peripheral nerve injury [119]. So far, the P2Y1 receptor is the only one of the $\mathrm{P} 2 \mathrm{Y}$ receptors studied in 
relation to cancer-induced bone pain (Table 1 ). In a recent study it was demonstrated that the level of $\mathrm{P} 2 \mathrm{Y} 1$ receptor mRNA is increased in the DRGs and spinal cord of rats with bone cancer and additionally that inhibiting the receptor with intrathecal injections of a P2Y1 receptor antagonist temporary attenuated the nociceptive behavior in the early stage of tumor growth [120]. This is in contrast to a previous report, suggesting that the $\mathrm{P} 2 \mathrm{Y} 1$ receptor might constitute an inhibiting role in release of nociceptive transmitters in the spinal cord by inhibiting the activity of the $\mathrm{P} 2 \mathrm{X} 3$ receptor $[121,122]$.

\section{Conclusion and Perspectives}

Even though the development of animal models has provided clues to the mechanisms underlying cancer-induced bone pain, much is still unknown. The role of purinergic signaling has begun to be elucidated and points to an involvement of the $\mathrm{P} 2 \mathrm{X} 3$ and $\mathrm{P} 2 \mathrm{X} 2 / 3$ receptors in the early development of cancer-induced bone pain. Other purinergic receptors such as P2X7 and P2Y1 have also been investigated; however, for the $\mathrm{P} 2 \mathrm{X} 7$ receptor the interpretation of the data is complicated by variation in the activation of glial cells in different in vivo models of cancer-induced bone pain. All data so far have been obtained in rat or mouse models and it remains to be established which model is the best representation of the human disease.

Purinergic signaling is complicated not only by involving numerous receptors that can combine both as homo- and heterotrimers, but also by the fact that released ATP can rapidly be degraded by ectonucleotidases thus producing $\mathrm{ADP}, \mathrm{AMP}$, and adenosine. Investigating these complex interactions in vivo is almost impossible, and we might have to wait for new research tools before getting a fuller picture of the role of purinergic signaling in chronic pain including cancer pain. Nevertheless, based on the knowledge we already have of the importance of the purinergic receptors in nociceptive signaling in other chronic pain states, it is reasonable to hypothesize that the purinergic receptors are important for the development of cancer-induced bone pain.

\section{References}

[1] A. Delaney, S. M. Fleetwood-Walker, L. A. Colvin, and M. Fallon, "Translational medicine: cancer pain mechanisms and management," British Journal of Anaesthesia, vol. 101, no. 1, pp. 87-94, 2008.

[2] C. Urch, "The pathophysiology of cancer-induced bone pain: Current understanding," Palliative Medicine, vol. 18, no. 4, pp. 267-274, 2004.

[3] H. S. Smith, "Painful osseous metastases," Pain Physician, vol. 14, no. 4, pp. E373-E405, 2011.

[4] S. Mercadante, "Malignant bone pain: pathophysiology and treatment," Pain, vol. 69, no. 1-2, pp. 1-18, 1997.

[5] S. Mercadante, "Managing breakthrough pain," Current Pain and Headache Reports, vol. 15, no. 4, pp. 244-249, 2011.

[6] P. G. Lawlor and E. Bruera, "Side-effects of opioids in chronic pain treatment," Current Opinion in Anaesthesiology, vol. 11, no. 5, pp. 539-545, 1998.
[7] P. Honore, S. D. Rogers, M. J. Schwei et al., "Murine models of inflammatory, neuropathic and cancer pain each generates a unique set of neurochemical changes in the spinal cord and sensory neurons," Neuroscience, vol. 98, no. 3, pp. 585-598, 2000.

[8] C. M. Peters, J. R. Ghilardi, C. P. Keyser et al., "Tumorinduced injury of primary afferent sensory nerve fibers in bone cancer pain," Experimental Neurology, vol. 193, no. 1, pp. 85-100, 2005.

[9] M. J. Schwei, P. Honore, S. D. Rogers et al., "Neurochemical and cellular reorganization of the spinal cord in a murine model of bone cancer pain," Journal of Neuroscience, vol. 19, no. 24, pp. 10886-10897, 1999.

[10] C. Pacharinsak and A. Beitz, "Animal models of cancer pain," Comparative Medicine, vol. 58, no. 3, pp. 220-233, 2008.

[11] M. A. Sevcik, J. R. Ghilardi, C. M. Peters et al., "AntiNGF therapy profoundly reduces bone cancer pain and the accompanying increase in markers of peripheral and central sensitization," Pain, vol. 115, no. 1-2, pp. 128-141, 2005.

[12] C. Geis, M. Graulich, A. Wissmann et al., "Evoked pain behavior and spinal glia activation is dependent on tumor necrosis factor receptor 1 and 2 in a mouse model of bone cancer pain," Neuroscience, vol. 169, no. 1, pp. 463-474, 2010.

[13] M. A. Sevcik, J. R. Ghilardi, K. G. Halvorson, T. H. Lindsay, K. Kubota, and P. W. Mantyh, "Analgesic efficacy of bradykinin B1 antagonists in a murine bone cancer pain model," Journal of Pain, vol. 6, no. 11, pp. 771-775, 2005.

[14] M. A. C. Sabino, J. R. Ghilardi, J. L. M. Jongen et al., "Simultaneous reduction in cancer pain, bone destruction, and tumor growth by selective inhibition of cyclooxygenase2," Cancer Research, vol. 62, no. 24, pp. 7343-7349, 2002.

[15] H. O. J. Collier, G. W. L. James, and C. Schneider, "Antagonism by aspirin and fenamates of bronchoconstriction and nociception induced by adenosine- $5^{\prime}$-triphosphate," Nature, vol. 212, no. 5060, pp. 411-412, 1966.

[16] G. Burnstock, "Purinergic receptors and pain," Current Pharmaceutical Design, vol. 15, no. 15, pp. 1717-1735, 2009.

[17] G. Burnstock, "A unifying purinergic hypothesis for the initiation of pain," The Lancet, vol. 347, no. 9015, pp. 16041605, 1996.

[18] M. Tsuda, H. Tozaki-Saitoh, and K. Inoue, "Pain and purinergic signaling," Brain Research Reviews, vol. 63, no. 12, pp. 222-232, 2010.

[19] C. Vial, J. A. Roberts, and R. J. Evans, "Molecular properties of ATP-gated P2X receptor ion channels," Trends in Pharmacological Sciences, vol. 25, no. 9, pp. 487-493, 2004.

[20] M. Hattori and E. Gouaux, "Molecular mechanism of ATP binding and ion channel activation in P2X receptors," Nature, vol. 485, pp. 207-212, 2012.

[21] T. Kawate, J. C. Michel, W. T. Birdsong, and E. Gouaux, "Crystal structure of the ATP-gated $\mathrm{P}_{2} \mathrm{X}_{4}$ ion channel in the closed state," Nature, vol. 460, no. 7255, pp. 592-598, 2009.

[22] L. E. Browne, L. H. Jiang, and R. A. North, "New structure enlivens interest in P2X receptors," Trends in Pharmacological Sciences, vol. 31, no. 5, pp. 229-237, 2010.

[23] R. A. North, "Molecular physiology of P2X receptors," Physiological Reviews, vol. 82, no. 4, pp. 1013-1067, 2002.

[24] F. Rassendren, G. N. Buell, C. Virginio, G. Collo, R. A. North, and A. Surprenant, "The permeabilizing ATP receptor, $\mathrm{P} 2 \mathrm{X}_{7}$. Cloning and expression of a human cDNA," The Journal of Biological Chemistry, vol. 272, no. 9, pp. 5482-5486, 1997. 
[25] V. Compan, L. Ulmann, O. Stelmashenko, J. Chemin, S. Chaumont, and F. Rassendren, " $\mathrm{P} 2 \mathrm{X}_{2}$ and $\mathrm{P} 2 \mathrm{X}_{5}$ subunits define a new heteromeric receptor with $\mathrm{P} 2 \mathrm{X}_{7}$-Like properties," The Journal of Neuroscience, vol. 32, no. 12, pp. 4284 4296, 2012.

[26] L. P. Bernier, A. R. Ase, E. Boué-Grabot, and P. Séguéla, “P2X receptor channels form large noncytolytic pores in resting and activated microglia," Glia, vol. 60 , no. 5, pp. 728-737, 2012.

[27] G. Burnstock, "Purinergic signalling: Its unpopular beginning, its acceptance and its exciting future," Bioessays, vol. 34, no. 3, pp. 218-225, 2012.

[28] R. A. Felix, S. Martin, S. Pinion, and D. J. Crawford, "Development of a comprehensive set of P2 receptor pharmacological research compounds," Purinergic Signalling, vol. 8, supplement 1, pp. 101-112, 2012.

[29] G. Lambrecht, T. Friebe, U. Grimm et al., "PPADS, a novel functionally selective antagonist of P2 purinoceptormediated responses," European Journal of Pharmacology, vol. 217, no. 2-3, pp. 217-219, 1992.

[30] K. Wirkner, B. Sperlagh, and P. Illes, "P2 $\mathrm{X}_{3}$ receptor involvement in pain states," Molecular Neurobiology, vol. 36, no. 2, pp. 165-183, 2007.

[31] D. Julius and A. I. Basbaum, "Molecular mechanisms of nociception," Nature, vol. 413, no. 6852, pp. 203-210, 2001.

[32] L. Djouhri and S. N. Lawson, "A $\beta$-fiber nociceptive primary afferent neurons: a review of incidence and properties in relation to other afferent a-fiber neurons in mammals," Brain Research Reviews, vol. 46, no. 2, pp. 131-145, 2004.

[33] T. P. Doubell, R. J. Mannion, and C. J. Woolf, “The dorsal horn: State-dependent sensory processing, plasticity and the generation of pain," in Textbook of Pain, P. D. Wall and R. Melzack, Eds., 4th edition, 1999.

[34] L. Vulchanova, M. S. Riedl, S. J. Shuster et al., "Immunohistochemical study of the $\mathrm{P} 2 \mathrm{X}_{2}$ and $\mathrm{P} 2 \mathrm{X}_{3}$ receptor subunits in rat and monkey sensory neurons and their central terminals," Neuropharmacology, vol. 36, no. 9, pp. 1229-1242, 1997.

[35] P. M. Dunn, Y. Zhong, and G. Burnstock, "P2X receptors in peripheral neurons," Progress in Neurobiology, vol. 65, no. 2, pp. 107-134, 2001.

[36] A. P. Ford, "In pursuit of $\mathrm{P}_{2} \mathrm{X}_{3}$ antagonists: novel therapeutics for chronic pain and afferent sensitization," Purinergic Signal, vol. 8, supplement 1, pp. 3-26, 2012.

[37] E. J. Bradbury, G. Burnstock, and S. B. McMahon, "The expression of $\mathrm{P}_{2} \mathrm{X}_{3}$ purinoreceptors in sensory neurons: effects of axotomy and glial-derived neurotrophic factor," Molecular and Cellular Neurosciences, vol. 12, no. 4-5, pp. 256-268, 1998.

[38] L. Vulchanova, M. S. Riedl, S. J. Shuster et al., " $\mathrm{P} 2 \mathrm{X}_{3}$ is expressed by DRG neurons that terminate in inner lamina II," European Journal of Neuroscience, vol. 10, no. 11, pp. 34703478, 1998.

[39] S. D. Novakovic, L. C. Kassotakis, I. B. Oglesby et al., "Immunocytochemical localization of $\mathrm{P}_{2 \times 3}$ purinoceptors in sensory neurons in naive rats and following neuropathic injury," Pain, vol. 80, no. 1-2, pp. 273-282, 1999.

[40] G. Y. Xu and L. Y. M. Huang, "Peripheral inflammation sensitizes $\mathrm{P} 2 \mathrm{X}$ receptor-mediated responses in rat dorsal root ganglion neurons," Journal of Neuroscience, vol. 22, no. 1, pp. 93-102, 2002.

[41] L. S. Gilchrist, D. M. Cain, C. Harding-Rose et al., "Reorganization of $\mathrm{P}_{2} \mathrm{X}_{3}$ receptor localization on epidermal nerve fibers in a murine model of cancer pain," Brain Research, vol. 1044, no. 2, pp. 197-205, 2005.
[42] K. Nagamine, N. Ozaki, M. Shinoda et al., "Mechanical allodynia and thermal hyperalgesia induced by experimental squamous cell carcinoma of the lower gingiva in rats," Journal of Pain, vol. 7, no. 9, pp. 659-670, 2006.

[43] Z. Xiang, X. Bo, and G. Burnstock, "Localization of ATPgated P2X receptor immunoreactivity in rat sensory and sympathetic ganglia," Neuroscience Letters, vol. 256, no. 2, pp. 105-108, 1998.

[44] J. A. Barden and M. R. Bennett, "Distribution of P2X purinoceptor clusters on individual rat dorsal root ganglion cells," Neuroscience Letters, vol. 287, no. 3, pp. 183-186, 2000.

[45] H. Z. Ruan and G. Burnstock, "Localisation of P2Y1 and $\mathrm{P} 2 \mathrm{Y} 4$ receptors in dorsal root, nodose and trigeminal ganglia of the rat," Histochemistry and Cell Biology, vol. 120, no. 5, pp. 415-426, 2003.

[46] R. Aoyama, Y. Okada, S. Yokota et al., "Spatiotemporal and anatomical analyses of $\mathrm{P} 2 \mathrm{X}$ receptor-mediated neuronal and glial processing of sensory signals in the rat dorsal horn," Pain, vol. 152, no. 9, pp. 2085-2097, 2011.

[47] R. Kanjhan, G. D. Housley, L. D. Burton et al., "Distribution of the $\mathrm{P}_{2} \mathrm{X}_{2}$ receptor subunit of the ATP-gated ion channels in the rat central nervous system," Journal of Comparative Neurology, vol. 407, no. 1, pp. 11-32, 1999.

[48] M. Tsuda, Y. Shigemoto-Mogami, S. Koizumi et al., "P2X receptors induced in spinal microglia gate tactile allodynia after nerve injury," Nature, vol. 424, no. 6950, pp. 778-783, 2003.

[49] Q. J. Gong, Y. Y. Li, W. J. Xin et al., "ATP induces longterm potentiation of C-fiber-evoked field potentials in spinal dorsal horn: the roles of $\mathrm{P}_{2} \mathrm{X}_{4}$ receptors and $\mathrm{p} 38$ MAPK in microglia," Glia, vol. 57, no. 6, pp. 583-591, 2009.

[50] S. Duan, C. M. Anderson, E. C. Keung, Y. Chen, Y. Chen, and R. A. Swanson, "P2 $\mathrm{X}_{7}$ receptor-mediated release of excitatory amino acids from astrocytes," Journal of Neuroscience, vol. 23, no. 4, pp. 1320-1328, 2003.

[51] M. Kukley, J. A. Barden, C. Steinhäuser, and R. Jabs, "Distribution of $\mathrm{P} 2 \mathrm{x}$ receptors on astrocytes in juvenile rat hippocampus," Glia, vol. 36, no. 1, pp. 11-21, 2001.

[52] W. Panenka, H. Jijon, L. M. Herx et al., "P2X $\mathrm{X}_{7}$-like receptor activation in astrocytes increases chemokine monocyte chemoattractant protein-1 expression via mitogen-activated protein kinase," Journal of Neuroscience, vol. 21, no. 18, pp. 7135-7142, 2001.

[53] S. O. Suadicani, C. F. Brosnan, and E. Scemes, "P2X receptors mediate ATP release and amplification of astrocytic intercellular $\mathrm{Ca}^{2+}$ signaling," Journal of Neuroscience, vol. 26, no. 5, pp. 1378-1385, 2006.

[54] A. K. Clark, A. A. Staniland, F. Marchand, T. K. Y. Kaan, S. B. McMahon, and M. Malcangio, "P2 $\mathrm{X}_{7}$-dependent release of interleukin- $1 \beta$ and nociception in the spinal cord following lipopolysaccharide," Journal of Neuroscience, vol. 30, no. 2, pp. 573-582, 2010.

[55] Y. X. Chu, Y. Zhang, Y. Q. Zhang, and Z. Q. Zhao, "Involvement of microglial $\mathrm{P} 2 \mathrm{X}_{7}$ receptors and downstream signaling pathways in long-term potentiation of spinal nociceptive responses," Brain, Behavior, and Immunity, vol. 24, no. 7, pp. 1176-1189, 2010.

[56] D. B. Mach, S. D. Rogers, M. C. Sabino et al., "Origins of skeletal pain: Sensory and sympathetic innervation of the mouse femur," Neuroscience, vol. 113, no. 1, pp. 155-166, 2002.

[57] C. M. Serre, D. Farlay, P. D. Delmas, and C. Chenu, "Evidence for a dense and intimate innervation of the bone tissue, 
including glutamate-containing fibers," Bone, vol. 25, no. 6, pp. 623-629, 1999.

[58] J. M. Jimenez-Andrade, W. G. Mantyh, A. P. Bloom et al., “A phenotypically restricted set of primary afferent nerve fibers innervate the bone versus skin: therapeutic opportunity for treating skeletal pain,” Bone, vol. 46, no. 2, pp. 306-313, 2010.

[59] J. J. Ivanusic, "Size, neurochemistry, and segmental distribution of sensory neurons innervating the rat tibia," Journal of Comparative Neurology, vol. 517, no. 3, pp. 276-283, 2009.

[60] I. R. Orriss, G. Burnstock, and T. R. Arnett, "Purinergic signalling and bone remodelling," Current Opinion in Pharmacology, vol. 10, no. 3, pp. 322-330, 2010.

[61] M. S. Morrison, L. Turin, B. F. King, G. Burnstock, and T. R. Arnett, "ATP is a potent stimulator of the activation and formation of rodent osteoclasts," Journal of Physiology, vol. 511, no. 2, pp. 495-500, 1998.

[62] B. F. King, L. E. Ziganshina, J. Pintor, and G. Burnstock, "Full sensitivity of $\mathrm{P}_{2} \mathrm{X}_{2}$ purinoceptor to ATP revealed by changing extracellular pH," British Journal of Pharmacology, vol. 117, no. 7, pp. 1371-1373, 1996.

[63] A. Hoebertz, A. Townsend-Nicholson, R. Glass, G. Burnstock, and T. R. Arnett, "Expression of P2 receptors in bone and cultured bone cells," Bone, vol. 27, no. 4, pp. 503-510, 2000.

[64] I. Orriss, S. Syberg, N. Wang et al., "Bone phenotypes of P2 receptor knockout mice," Frontiers in Bioscience, vol. 3, pp. 1038-1046, 2011.

[65] A. Hald, R. R. Hansen, M. W. Thomsen et al., "Cancerinduced bone loss and associated pain-related behavior is reduced by risedronate but not its phosphonocarboxylate analog NE-10790," International Journal of Cancer, vol. 125, no. 5, pp. 1177-1185, 2009.

[66] W. G. Mantyh, J. M. Jimenez-Andrade, J. I. Stake et al., "Blockade of nerve sprouting and neuroma formation markedly attenuates the development of late stage cancer pain,” Neuroscience, vol. 171, no. 2, pp. 588-598, 2010.

[67] T. K. Y. Kaan, P. K. Yip, S. Patel et al., "Systemic blockade of $\mathrm{P} 2 \mathrm{X}_{3}$ and $\mathrm{P} 2 \mathrm{X}_{2 / 3}$ receptors attenuates bone cancer pain behaviour in rats," Brain, vol. 133, no. 9, pp. 2549-2564, 2010.

[68] S. González-Rodríguez, M. Pevida, B. P. Roques et al., "Involvement of enkephalins in the inhibition of osteosarcoma-induced thermal hyperalgesia evoked by the blockade of peripheral $\mathrm{P} 2 \mathrm{X}_{3}$ receptors," Neuroscience Letters, vol. 465, no. 3, pp. 285-289, 2009.

[69] R. R. Hansen, A. Nasser, S. Falk et al., "Chronic administration of the selective $\mathrm{P} 2 \mathrm{X}_{3}, \mathrm{P}_{2} \mathrm{X}_{2} / 3$ receptor antagonist, A317491 , transiently attenuates cancer-induced bone pain in mice," European Journal of Pharmacology, vol. 688, no. 1-3, pp. 27-34, 2012.

[70] J. X. Wu, M. Y. Xu, and X. R. Miao, "Functional up-regulation of $\mathrm{P}_{2} \mathrm{X}_{3}$ receptors in dorsal root ganglion in a rat model of bone cancer pain," European Journal of Pain. In press.

[71] M. S. Ramer, E. J. Bradbury, and S. B. McMahon, "Nerve growth factor induces $\mathrm{P}_{2} \mathrm{X}_{3}$ expression in sensory neurons," Journal of Neurochemistry, vol. 77, no. 3, pp. 864-875, 2001.

[72] M. F. Jarvis, "The neural-glial purinergic receptor ensemble in chronic pain states," Trends in Neurosciences, vol. 33, no. 1, pp. 48-57, 2010.

[73] M. F. Jarvis, E. C. Burgard, S. McGaraughty et al., "A-317491, a novel potent and selective non-nucleotide antagonist of $\mathrm{P}_{2} \mathrm{X}_{3}$ and $\mathrm{P} 2 \mathrm{X}_{2 / 3}$ receptors, reduces chronic inflammatory and neuropathic pain in the rat," Proceedings of the National Academy of Sciences of the United States of America, vol. 99, no. 26, pp. 17179-17184, 2002.

[74] S. McGaraughty, P. Honore, C. T. Wismer et al., "Endogenous opioid mechanisms partially mediate $\mathrm{P}_{2} \mathrm{X}_{3} / \mathrm{P}_{2} \mathrm{X}_{2 / 3}-$ related antinociception in rat models of inflammatory and chemogenic pain but not neuropathic pain," British Journal of Pharmacology, vol. 146, no. 2, pp. 180-188, 2005.

[75] R. R. Ji, R. W. Gereau, M. Malcangio, and G. R. Strichartz, "MAP kinase and pain," Brain Research Reviews, vol. 60, no. 1, pp. 135-148, 2009.

[76] L. N. Naemsch, A. F. Weidema, S. M. Sims, T. M. Underhill, and S. J. Dixon, "P2X $\mathrm{X}_{4}$ purinoceptors mediate an ATPactivated, non-selective cation current in rabbit osteoclasts," Journal of Cell Science, vol. 112, no. 23, pp. 4425-4435, 1999.

[77] C. J. Woolf and M. W. Salter, "Neuronal plasticity: increasing the gain in pain," Science, vol. 288, no. 5472, pp. 1765-1768, 2000.

[78] P. Honore, N. M. Luger, M. A. C. Sabino et al., "Osteoprotegerin blocks bone cancer-induced skeletal destruction, skeletal pain and pain-related neurochemical reorganization of the spinal cord," Nature Medicine, vol. 6, no. 5, pp. 521$528,2000$.

[79] A. Hald, S. Nedergaard, R. R. Hansen, M. Ding, and A. M. Heegaard, "Differential activation of spinal cord glial cells in murine models of neuropathic and cancer pain," European Journal of Pain, vol. 13, no. 2, pp. 138-145, 2009.

[80] P. Illes, A. Verkhratsky, G. Burnstock, and H. Franke, "P2X receptors and theirroles in astroglia in the central and peripheral nervous system," The Neuroscientist. In press.

[81] R. D. Fields and G. Burnstock, "Purinergic signalling in neuron-glia interactions," Nature Reviews Neuroscience, vol. 7, no. 6, pp. 423-436, 2006.

[82] L. Ulmann, J. P. Hatcher, J. P. Hughes et al., "Up-regulation of $\mathrm{P}_{2} \mathrm{X}_{4}$ receptors in spinal microglia after peripheral nerve injury mediates BDNF release and neuropathic pain," Journal of Neuroscience, vol. 28, no. 44, pp. 11263-11268, 2008.

[83] T. Trang, S. Beggs, X. Wan, and M. W. Salter, "P2X $\mathrm{X}_{4}$ receptor-mediated synthesis and release of brain-derived neurotrophic factor in microglia is dependent on calcium and p38-mitogen-activated protein kinase activation," Journal of Neuroscience, vol. 29, no. 11, pp. 3518-3528, 2009.

[84] J. A. M. Coull, S. Beggs, D. Boudreau et al., "BDNF from microglia causes the shift in neuronal anion gradient underlying neuropathic pain," Nature, vol. 438, no. 7070, pp. 1017-1021, 2005.

[85] D. Ferrari, C. Pizzirani, E. Adinolfi et al., "The $\mathrm{P} 2 \mathrm{X}_{7}$ receptor: a key player in IL-1 processing and release," Journal of Immunology, vol. 176, no. 7, pp. 3877-3883, 2006.

[86] I. Hide, M. Tanaka, A. Inoue et al., "Extracellular ATP triggers tumor necrosis factor- $\alpha$ release from rat microglia," Journal of Neurochemistry, vol. 75, no. 3, pp. 965-972, 2000.

[87] T. Suzuki, I. Hide, K. Ido, S. Kohsaka, K. Inoue, and Y. Nakata, "Production and release of neuroprotective tumor necrosis factor by $\mathrm{P}_{2} \mathrm{X}_{7}$ receptor-activated microglia," Journal of Neuroscience, vol. 24, no. 1, pp. 1-7, 2004.

[88] K. Inoue, "P2 receptors and chronic pain," Purinergic Signalling, vol. 3, no. 1-2, pp. 135-144, 2007.

[89] F. Bianco, E. Pravettoni, A. Colombo et al., "Astrocytederived ATP induces vesicle shedding and IL- $1 \beta$ release from microglia," Journal of Immunology, vol. 174, no. 11, pp. 7268 7277, 2005. 
[90] V. Montana, E. B. Malarkey, C. Verderio, M. Matteoli, and V. Parpura, "Vesicular transmitter release from astrocytes," Glia, vol. 54, no. 7, pp. 700-715, 2006.

[91] C. E. Stout, J. L. Costantin, C. C. G. Naus, and A. C. Charles, "Intercellular calcium signaling in astrocytes via ATP release through connexin hemichannels," The Journal of Biological Chemistry, vol. 277, no. 12, pp. 10482-10488, 2002.

[92] S. Li, I. Bjelobaba, Z. Yan, M. Kucka, M. Tomić, and S. S. Stojilkovic, "Expression and roles of pannexins in ATP release in the pituitary gland," Endocrinology, vol. 152, no. 6, pp. 2342-2352, 2011.

[93] S. Duan and J. T. Neary, "P2X $\mathrm{X}_{7}$ receptors: properties and relevance to CNS function," Glia, vol. 54, no. 7, pp. 738-746, 2006.

[94] B. Sung, G. Lim, and J. Mao, "Altered expression and uptake activity of spinal glutamate transporters after nerve injury contribute to the pathogenesis of neuropathic pain in rats," Journal of Neuroscience, vol. 23, no. 7, pp. 2899-2910, 2003.

[95] W. Wang, W. Wang, Y. Wang, J. Huang, S. Wu, and Y. Q. $\mathrm{Li}$, "Temporal changes of astrocyte activation and glutamate transporter-1 expression in the spinal cord after spinal nerve ligation-induced neuropathic pain," Anatomical Record, vol. 291, no. 5, pp. 513-518, 2008.

[96] W. J. Xin, H. R. Weng, and P. M. Dougherty, "Plasticity in expression of the glutamate transporters GLT-1 and GLAST in spinal dorsal horn glial cells following partial sciatic nerve ligation," Molecular Pain, vol. 5, article 15, 2009.

[97] V. L. Tawfik, M. R. Regan, C. Haenggeli et al., "Propentofylline-induced astrocyte modulation leads to alterations in glial glutamate promoter activation following spinal nerve transection," Neuroscience, vol. 152, no. 4, pp. 1086 1092, 2008.

[98] Y. P. Liu, C. S. Yang, M. C. Chen, S. H. Sun, and S. F. Tzeng, " $\mathrm{Ca}^{2+}$-dependent reduction of glutamate aspartate transporter GLAST expression in astrocytes by $\mathrm{P}_{2} \mathrm{X}_{7}$ receptormediated phosphoinositide 3-kinase signaling," Journal of Neurochemistry, vol. 113, no. 1, pp. 213-227, 2010.

[99] J. C. Lo, W. C. Huang, Y. C. Chou, C. H. Tseng, W. L. Lee, and S. H. Sun, "Activation of $\mathrm{P}_{2} \mathrm{X}_{7}$ receptors decreases glutamate uptake and glutamine synthetase activity in RBA-2 astrocytes via distinct mechanisms," Journal of Neurochemistry, vol. 105, no. 1, pp. 151-164, 2008.

[100] N. Morioka, M. J. Abdin, T. Kitayama, K. Morita, Y. Nakata, and $\mathrm{T}$. Dohi, "P2X $\mathrm{X}_{7}$ receptor stimulation in primary cultures of rat spinal microglia induces downregulation of the activity for glutamate transport," Glia, vol. 56, no. 5, pp. 528-538, 2008.

[101] S. Chaumont and B. S. Khakh, "Patch-clamp coordinated spectroscopy shows $\mathrm{P}_{2} \mathrm{X}_{2}$ receptor permeability dynamics require cytosolic domain rearrangements but not Panx-1 channels," Proceedings of the National Academy of Sciences of the United States of America, vol. 105, no. 33, pp. 1206312068, 2008.

[102] V. Poornima, M. Madhupriya, S. Kootar, G. Sujatha, A. Kumar, and A. K. Bera, "P2X 7 receptor-pannexin 1 hemichannel association: effect of extracellular calcium on membrane permeabilization," Journal of Molecular Neuroscience, vol. 46, no. 3, pp. 585-594, 2012.

[103] P. Pelegrin and A. Surprenant, "Pannexin-1 mediates large pore formation and interleukin- $1 \beta$ release by the ATP-gated $\mathrm{P}_{2} \mathrm{X}_{7}$ receptor," EMBO Journal, vol. 25, no. 21, pp. 50715082, 2006.
[104] S. Locovei, E. Scemes, F. Qiu, D. C. Spray, and G. Dahl, "Pannexin1 is part of the pore forming unit of the $\mathrm{P} 2 \mathrm{X}_{7}$ receptor death complex," FEBS Letters, vol. 581, no. 3, pp. 483-488, 2007.

[105] T. M. Egan, D. S. K. Samways, and Z. Li, "Biophysics of P2X receptors," Pflugers Archiv European Journal of Physiology, vol. 452, no. 5, pp. 501-512, 2006.

[106] P. Pelegrín, "Many ways to dilate the $\mathrm{P}_{2} \mathrm{X}_{7}$ receptor pore," British Journal of Pharmacology, vol. 163, no. 5, pp. 908-911, 2011.

[107] C. Marques-Da-Silva, M. M. Chaves, N. G. Castro, R. Coutinho-Silva, and M. Z. P. Guimaraes, "Colchicine inhibits cationic dye uptake induced by ATP in $\mathrm{P}_{2} \mathrm{X}_{2}$ and $\mathrm{P} 2 \mathrm{X}_{7}$ receptor-expressing cells: implications for its therapeutic action," British Journal of Pharmacology, vol. 163, no. 5, pp. 912-926, 2011.

[108] X. J. Xu, M. Boumechache, L. E. Robinson et al., "Splicevariants of the $\mathrm{P}_{2} \mathrm{X}_{7}$ receptor reveal differential agonistdependence and functional coupling with pannexin-1," Journal of Cell Science. In press.

[109] S. J. Fuller, L. Stokes, K. K. Skarratt, B. J. Gu, and J. S. Wiley, "Genetics of the $\mathrm{P}_{2} \mathrm{X}_{7}$ receptor and human disease," Purinergic Signalling, vol. 5, no. 2, pp. 257-262, 2009.

[110] C. M. Miller, A. M. Zakrzewski, R. J. Ikin et al., "Dysregulation of the inflammatory response to the parasite, toxoplasma gondii, in $\mathrm{P}_{2} \mathrm{X}_{7}$ receptor-deficient mice," International Journal for Parasitology, vol. 41, no. 3, pp. 301-308, 2011.

[111] R. E. Sorge, T. Trang, R. Dorfman et al., "Genetically determined $\mathrm{P} 2 \mathrm{X}_{7}$ receptor pore formation regulates variability in chronic pain sensitivity," Nature Medicine, vol. 18, no. 4, pp. 595-599, 2012.

[112] I. P. Chessell, J. P. Hatcher, C. Bountra et al., "Disruption of the $\mathrm{P}_{2} \mathrm{X}_{7}$ purinoceptor gene abolishes chronic inflammatory and neuropathic pain," Pain, vol. 114, no. 3, pp. 386-396, 2005.

[113] R. R. Hansen, C. K. Nielsen, A. Nasser et al., "P2X 7 receptordeficient mice are susceptible to bone cancer pain," Pain, vol. 152, no. 8, pp. 1766-1776, 2011.

[114] M. Yao, X. Chang, Y. Chu et al., "Antiallodynic effects of propentofylline elicited by interrupting spinal glial function in a rat model of bone cancer pain," Journal of Neuroscience Research, vol. 89, no. 11, pp. 1877-1886, 2011.

[115] L. N. Wang, J. P. Yang, and Y. Zhan, "Minocycline-induced reduction of brain-derived neurotrophic factor expression in relation to cancer-induced bone pain in rats," Journal of Neuroscience Research, vol. 90, no. 3, pp. 672-681, 2012.

[116] A. Nicke, Y. H. Kuan, M. Masin et al., "A functional P2X splice variant with an alternative transmembrane domain 1 escapes gene inactivation in $\mathrm{P}_{2} \mathrm{X}_{7}$ knock-out mice," The Journal of Biological Chemistry, vol. 284, no. 38, pp. 2581325822, 2009.

[117] K. Kobayashi, H. Yamanaka, T. Fukuoka, Y. Dai, K. Obata, and K. Noguchi, "P2Y12 receptor upregulation in activated microglia is a gateway of p38 signaling and neuropathic pain," Journal of Neuroscience, vol. 28, no. 11, pp. 2892-2902, 2008.

[118] H. Tozaki-Saitoh, M. Tsuda, H. Miyata, K. Ueda, S. Kohsaka, and $\mathrm{K}$. Inoue, "P2Y12 receptors in spinal microglia are required for neuropathic pain after peripheral nerve injury," Journal of Neuroscience, vol. 28, no. 19, pp. 4949-4956, 2008.

[119] H. S. Xiao, Q. H. Huang, F. X. Zhang et al., "Identification of gene expression profile of dorsal root ganglion in the rat 
peripheral axotomy model of neuropathic pain," Proceedings of the National Academy of Sciences of the United States of America, vol. 99, no. 12, pp. 8360-8365, 2002.

[120] J. Chen, L. Wang, Y. ZhangYang J., and J. Yang, "P2Y1 purinoceptor inhibition reduces extracellular signalregulated protein kinase $1 / 2$ phosphorylation in spinal cord and dorsal root ganglia: implications for cancer-induced bone pain," Acta Biochimica et Biophysica Sinica, vol. 44, no. 4, pp. 367-372, 2012.

[121] G. Burnstock, "Physiology and pathophysiology of purinergic neurotransmission," Physiological Reviews, vol. 87, no. 2, pp. 659-797, 2007.

[122] Z. Gerevich, C. Müller, and P. Illes, "Metabotropic P2Y1 receptors inhibit $\mathrm{P}_{2} \mathrm{X}_{3}$ receptor-channels in rat dorsal root ganglion neurons," European Journal of Pharmacology, vol. 521, no. 1-3, pp. 34-38, 2005. 


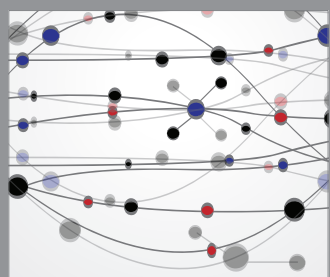

The Scientific World Journal
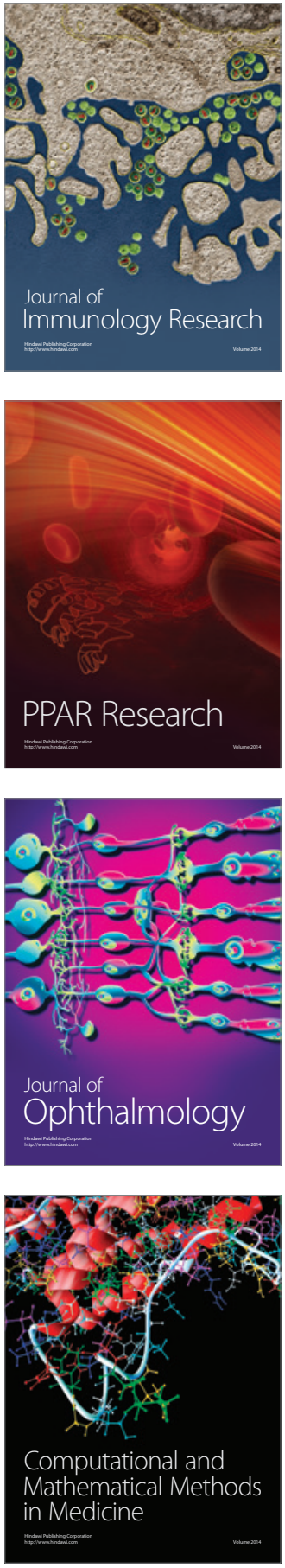

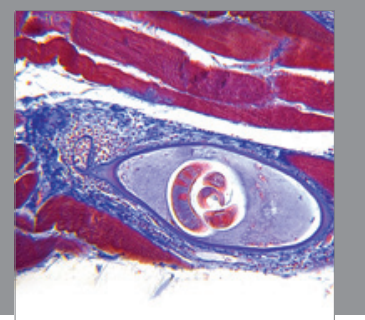

Gastroenterology

Research and Practice
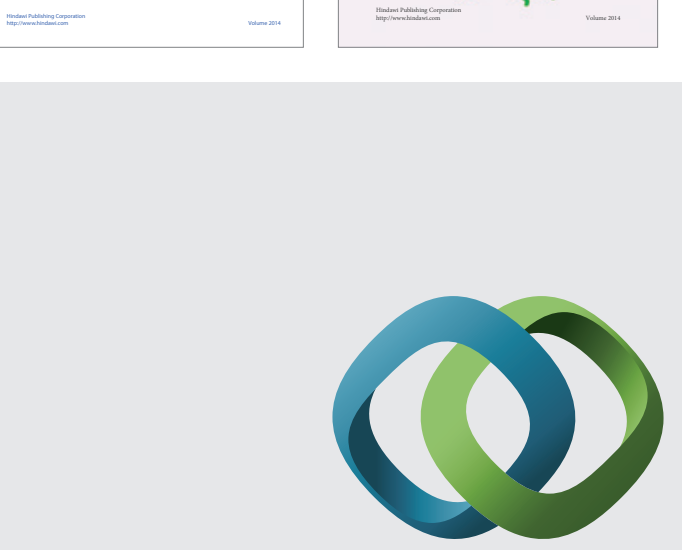

\section{Hindawi}

Submit your manuscripts at

http://www.hindawi.com
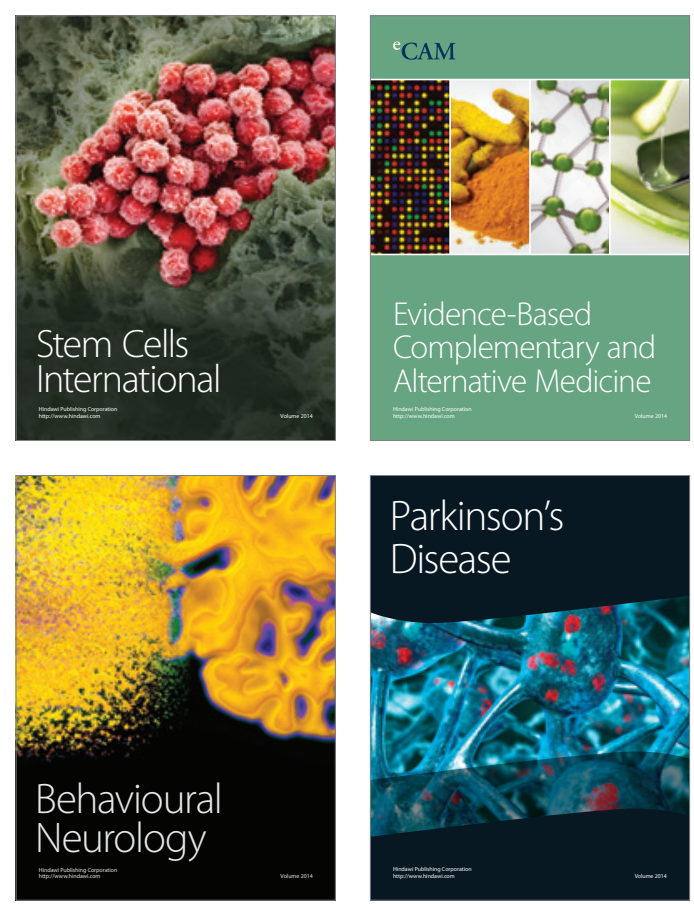

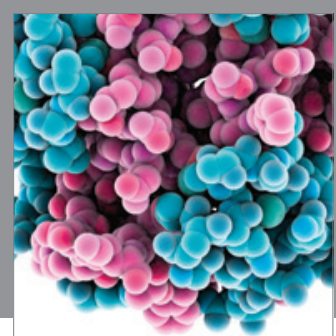

Journal of
Diabetes Research

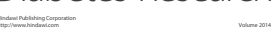

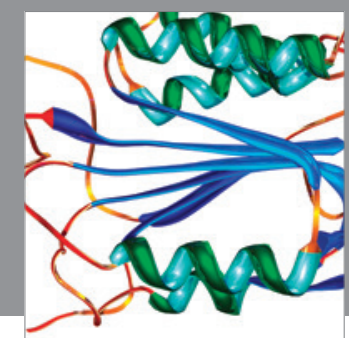

Disease Markers
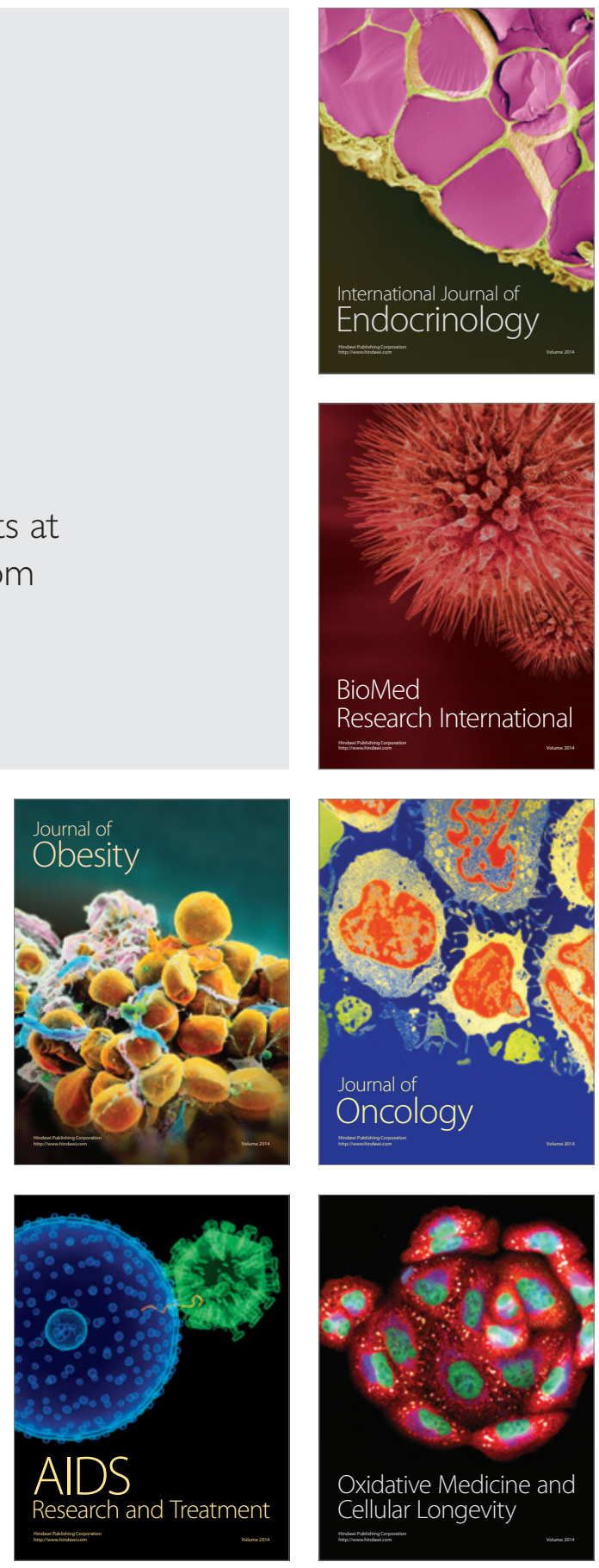